\title{
Zinc Amendment Decreased Nutrient Contents of Liquid Organic Fertilizer
}

\author{
F. Fahrurrozi ${ }^{1 *}$, Z. Muktamar ${ }^{2}$, S. Sudjatmiko ${ }^{1}$ N. Setyowati ${ }^{1}$, M. Chozin ${ }^{1}$, D. \\ N. Sari ${ }^{3}$, E. R. Togatorop ${ }^{3}$, U. Salamah ${ }^{1}$ \\ ${ }^{1}$ Department of Crop Production, University of Bengkulu, Bengkulu, 38121, Indonesia \\ ${ }^{2}$ Department of Soil Science, University of Bengkulu, Bengkulu, 38121, Indonesia \\ ${ }^{3}$ Faculty of Agriculture, Universitas Ratu Samban, Arga Makmur, 38618, Indonesia \\ *Corresponding author: fahrurrozi@unib.ac.id
}

\begin{abstract}
The use liquid organic fertilizer (LOF) has been found to be effective as complimentary nutrients for solid organic fertilizer in organic vegetable production. The amendment of zinc $(\mathrm{Zn})$ increased the activities of decomposing microbes to decompose solid organic fertilizer which eventually increased nutrient contents. However, reports on the effects of $\mathrm{Zn}$ addition in the production process of LOF on its nutrient properties are very limited. This experiment was, therefore, established to determine the effect of the $\mathrm{Zn}$ amendment on LOF nutrient contents. An experiment was conducted using randomized complete design with three replications. Treatments consisted of $0,25,50,75$, and 100 $\mathrm{ppm}$ of $\mathrm{Zn}$ that amended during the production of LOF. Results indicated that the addition of $\mathrm{Zn}$ significantly decreased $\mathrm{N}$ and organic $\mathrm{C}$ of LOF. However, $\mathrm{Zn}$ amendment did not significantly decrease $\mathrm{P}$ and $\mathrm{K}$ contents. In addition, decreased $\mathrm{N}$ was significantly correlated with decreased organic $\mathrm{C}$, but decreased $\mathrm{P}$ and $\mathrm{K}$ in LOF nutrients were not correlated with decreased organic $\mathrm{C}$ content. Future research should consider using lower $\mathrm{Zn}$ concentrations in the process of LOF production.
\end{abstract}

Keywords: Liquid Organic Fertilizer, Zn Amendment, Nutrient Contents

\section{INTRODUCTION}

In organic vegetable production, the effectiveness of solid organic fertilizer application to enhance crop growth and yields increased with additional application of liquid organic fertilizer (LOF). Previous research concluded that successful vegetable productions in organic soil required nitrogen amendment through foliar application to support for low availability of nitrogen [1] (Hartz et al., 2000). Recently, [2] Muktamar et al. (2017) confirmed that increased of organic sweet corn production was attributed to combining application of solid organic fertilizer with LOF application. Such complimentary effects were attributed to early supply of nutrients for early growth of vegetable crops since most vegetables have short-life cycles. The effectiveness of LOF to support crop growth and development were mainly determined by its nutrient contents.

Nutrient contents of particular LOF are mainly determined by its composing materials, including green biomasses, animal manures, microorganisms and other locally available decomposing materials [3] (Fahrurrozi et al., 2017a; [4] 2020; [5] Purnomo et al., 2017). Decomposition rates of organic materials are very complex processes which involve not only the characteristic of organic materials, but also rely on the activities of microorganisms as decomposers in suitable environmental conditions. Microorganisms might interact with particular nutrient to get more activated in decomposing organic materials in producing both macro and micro nutrients. Efforts to improve LOF nutrient contents for organic vegetable production must be continually conducted, including the addition of micronutrient during the process of LOF production.

The addition of zinc ( $\mathrm{Zn}$ ) micronutrient during the production of LOF might be considerably evaluated. According to [6] Chen et al. (2014), during the thermophilic phase of decomposition process, $\mathrm{Zn}$ enhanced decomposing-microbes to decay organic materials. The use of zinc enriched compost into NPK fertilizer was practiced by [7] Veeranagappa et al. (2010) and concluded that zinc enriched compost increased growth and yield of rice. Such increased might have been attributed by the increase of nutrient contents in organic compost resulted from stimulating effects of $\mathrm{Zn}$ on activities of microbial decomposers. In addition, [8] Duan et al. (2015) concluded that the combination of zinc with sulphamethazine during composting was better than individual addition of $\mathrm{Zn}$ and sulphamethazine in promoting micro-bacterial activities. Amendment of micronutrient in the production of solid organic fertilizer was also 
previously documented by [9] Zaccheo et al. (1996) Nevertheless, there have been no reports on the incorporation of $\mathrm{Zn}$ in the production of LOF. Should the amendment of $\mathrm{Zn}$ micronutrient is found to be effective to increase LOF nutrient contents, the use of natural organic wastes or green plants with rich $\mathrm{ZnO}$ content could be deployed for the production of LOF. There are many green plants of organic wastes were reported to have $\mathrm{ZnO}$ content, for example, Moringa oleifera, also commonly known as 'drumstick tree' or 'horseradish tree' [10] (Gopalakrishnan et al., 2016) and fruit peels [11] (Nava et al., 2017). This research aimed to determine the effect of $\mathrm{Zn}$ addition in the process of LOF production on $\mathrm{N}, \mathrm{P}, \mathrm{K}$ and organic $\mathrm{C}$ contents.

\section{MATERIALS AND METHOD}

An experiment was conducted in Field Laboratory Faculty of Agriculture, University of Bengkulu, Medan Baru, Bengkulu, from August to October 2019 using a complete randomized design with three replications. Treatments consisted of 0,25 , 50,75 , and $100 \mathrm{ppm}$ of $\mathrm{Zn}$ that added in the production of LOF. Materials used for LOF were $5 \mathrm{~kg}$ fresh cattle's feces, 10 cattle's urine, $2.5 \mathrm{~kg}$ topsoil, $5 \mathrm{~kg}$ Tithonia diversifolia leaves, $10 \mathrm{~L}$ solution of 24-hour incubated $10 \mathrm{~mL} \mathrm{EM} 4+0.125 \mathrm{~kg}$ white sugar [12] (Muktamar et al., 2016). Each treatment unit was amended with $\mathrm{Zn}$ accordingly, mixed with water to reach a volume of $100 \mathrm{~L}$, securely covered and incubated for five weeks in a blue plastic container. Each container was weekly stirred to provide sufficient aerobic environment in the decomposition process. All the containers were placed in the production house to prevent direct sunlight and precipitation.

Sample of $100 \mathrm{~mL}$ from each treatment was collected for nutrient content analysis. The proximate analysis of nutrient contents, $\mathrm{N}(\%), \mathrm{P}(\%), \mathrm{K}(\%)$, and organic-C (\%) were determined by using methods proposed by [13] Yoshida et al. (1976) at the Laboratory of Soil Science University of Bengkulu. Results were exposed to analysis of variance using $\mathrm{SAS}$ at $\mathrm{P}<0.05$. Trends of significant responses were summarized from Polynomial orthogonal analysis. Relationships between $\mathrm{N}, \mathrm{P}$, and $\mathrm{K}$ with organic $\mathrm{C}$ were determined by using SAS $(\mathrm{P}>0.05)$.

\section{RESULTS AND DISCUSSION}

Results indicated that the addition of $\mathrm{Zn}$ significantly affected $\mathrm{N}$ content $(\mathrm{P}<\mathrm{F}=0.0100)$ and organic- $\mathrm{C}(\mathrm{P}<\mathrm{F}=0.0400)$, but not the $\mathrm{P}(\mathrm{P}<\mathrm{F}=0.9700)$ and $\mathrm{K}(\mathrm{P}<\mathrm{F}=0.7100)$ of LOF. Clearly, $\mathrm{Zn}$ amendment during the LOF production process decreased $\mathrm{N}$ and organic $\mathrm{C}$ contents of LOF. Declining trends were also noticed on $\mathrm{P}$ and $\mathrm{K}$ contents. The average $\mathrm{N}, \mathrm{P}, \mathrm{K}$ and organic $\mathrm{C}$ contents of LOF in response to addition of $\mathrm{Zn}$ during the production of LOF are summarized in Table 1 .

Table1. Effect of $\mathrm{Zn}$ amendment during LOF production process on $\mathrm{N}, \mathrm{P}, \mathrm{K}$ and organic $\mathrm{C}$ contents

\begin{tabular}{ccccc}
\hline $\begin{array}{c}\text { Zn concentration } \\
(\mathrm{ppm})\end{array}$ & $\begin{array}{c}\mathrm{N} \\
(\%)\end{array}$ & $\begin{array}{c}\mathrm{P} \\
(\%)\end{array}$ & $\begin{array}{c}\mathrm{K} \\
(\%)\end{array}$ & $\begin{array}{c}\text { Organic } \\
\mathrm{C}(\%)\end{array}$ \\
\hline $\mathrm{K} 0$ & $0.77 \mathrm{a}$ & 0.21 & 0.98 & $0.96 \mathrm{a}$ \\
$\mathrm{K} 1$ & $0.51 \mathrm{~b}$ & 0.20 & 0.89 & $0.81 \mathrm{ab}$ \\
$\mathrm{K} 2$ & $0.46 \mathrm{~b}$ & 0.21 & 0.88 & $0.66 \mathrm{~b}$ \\
$\mathrm{~K} 3$ & $0.39 \mathrm{~b}$ & 0.23 & 0.84 & $0.78 \mathrm{ab}$ \\
$\mathrm{K} 4$ & $0.37 \mathrm{~b}$ & 0.18 & 0.87 & $0.72 \mathrm{~b}$ \\
\hline
\end{tabular}

Notes: Treatment means in the same column followed with the same letter are not significantly different according to Least Significant Different at 5\%

The use of $\mathrm{Zn}$ during the production of LOF decreased $\mathrm{N}$ contents (Table 1). On average, the magnitude of $\mathrm{N}$ decrease was $44 \%$, with a linear relationships $\left(\mathrm{P}<\mathrm{F}=0.0057, \mathrm{y}=-0.0036 \mathrm{x}+0.686, \mathrm{R}^{2}=0.8213\right.$ ) (Figure 1$)$. 


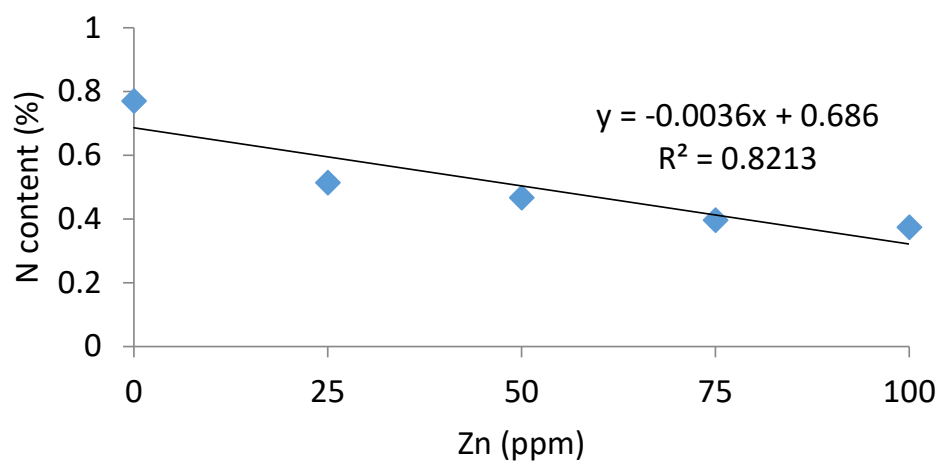

Figure 1. Relationship between $\mathrm{Zn}$ concentration and $\mathrm{N}$ content in liquid organic fertilizer (\%)

Insignificant effects of $\mathrm{Zn}$ amendment on $\mathrm{P}$ and $\mathrm{K}$ in LOF was also less likely expected. In addition, results also suggested that decreased organic $\mathrm{C}$ content was $44 \%$ and followed a linear relationships $(\mathrm{P}<\mathrm{F}=0.0004, \mathrm{y}=-$ $\left.0.0002 x+0.8907, R^{2}=0.5005\right)$ (Figure 2).

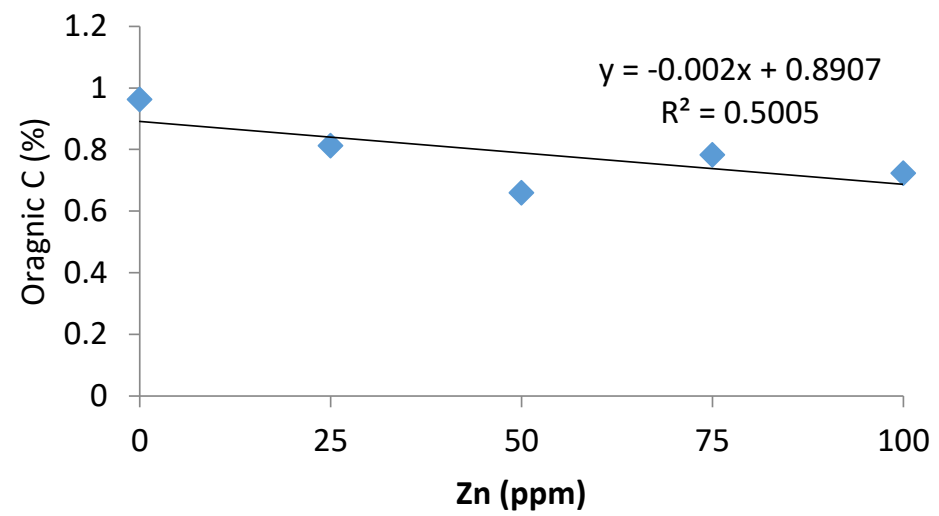

Figure 2. Relationship between $\mathrm{Zn}$ concentration and organic $\mathrm{C}$ content in liquid organic fertilizer (\%)

It appeared that the roles of composting microbes during the organic matter decomposition might have affected by $\mathrm{Zn}$ addition during the LOF production process. The rate of organic material decomposition is mainly determined by the microorganism activities [14] (Lee, 2016). Both fungi and bacteria play important roles in organic matter decomposition. [15] Fahrurrozi et al. (2017b) found that there are eight genus of fungus that played important roles in organic matter decomposition during the production of LOF, namely Saccharomyces, Phanerochaete, Aspergillus, Trichoderma, Gliocladium, Monosporium, Paecilomyces, dan Hyalondendron. Meanwhile [5] Purnomo et al (2017) reported that bacteria of Pseudomonas and Staphylococcus plays important roles in LOF decomposition process. Although $\mathrm{Zn}$ amendment was claimed to have positive effects by enhancing microbial activities to decompose organic matters [7] (Veeranagappa et al., 2010; [7] Duan et al., 2015) which eventually increased $\mathrm{N}, \mathrm{P}, \mathrm{K}$ contents in LOF, high concentration of $\mathrm{Zn}$ might be harmful to microbes which eventually inhibit or decrease nutrient production. Decreased $\mathrm{N}$ content was strongly correlated with decreased organic $\mathrm{C}$ in LOF $(\mathrm{P}<\mathrm{F}=0.0023, \mathrm{r}=0.7239)$, indicating that organic material was not abundantly decomposed by LOF microorganisms. $\mathrm{N}$ reduction might have related to detrimental effects of $\mathrm{Zn}$ to bacteria that involves in organic matter decomposition. Research conducted by [16] Bong et al. (2010) concluded that high concentration of $\mathrm{Zn}$ decreased aminopeptidase activities of bacteria which eventually decreased its ability or decompose organic matter. Aminopeptidase is an enzyme that selectively hydrolyzes peptide bonds at the N-terminal of a protein [17] (Gonzales and Robert-Baodouy, 1996). In addition, insignificant effects of $\mathrm{Zn}$ on $\mathrm{P}$ and $\mathrm{K}$ concentration in LOF were more likely related to injurious effects of $\mathrm{Zn}$ on microbial activities and had no relationship with decreased of $\mathrm{C}$ content in LOF. The relationships between $\mathrm{P}$ and $\mathrm{K}$ concentrations with organic $\mathrm{C}$ concentration were insignificant as well $(\mathrm{P}$ with $\mathrm{C}, \mathrm{P}<\mathrm{F}=0.15781$, $\mathrm{r}=0.5743$, and $\mathrm{K}$ with $\mathrm{C}, \mathrm{P}<\mathrm{F}=0.49921, \mathrm{r}=0.0582$ ). Such effects might have also related to declining effects a number of enzymes from bacteria and fungi that involved in the degradation of organic matter of LOF composing materials. According to [18] Rashid et al. (2016), solubilizing bacteria and fungi played important roles in $\mathrm{P}$ and $\mathrm{K}$ availability during the organic matter biodegradation. Insignificant 
effect of $\mathrm{Zn}$ to The mechanisms might be due to high concentration of $\mathrm{Zn}$ used in this experiment reduced the ability of phosphomonoesterase enzymes to degrade $\mathrm{P}$ during the LOF decomposition. In addition, solubilizing bacteria such might have weakened due to the presence of high concentration of $\mathrm{Zn}$ amended in the production of LOF.

Decreased of organic $\mathrm{C}$ content due to $\mathrm{Zn}$ amendment (Figure 2) was presumably resulted from declining aminopeptidase activities of bacteria as well as attributed to weakening ability of phosphor and potassium solubilizing bacteria to decompose organic matter, such as cellulose, lignin, hemicelluloses, chitin and lipids present in the LOF composing materials. According to [19] Khatoon et al. (2017) organic matter decomposition is mostly microbial-mediated process and its rates were determined by temperatures, oxygen, moisture, nitrogen content and the quantity and quality of carbon substrates.

\section{CONCLUSION}

On the basis of this research it was concluded that the amendment of $\mathrm{Zn}$ during the production of liquid organic fertilizer decreased nutrient $\mathrm{N}$ and organic $\mathrm{C}$ contents. Similar trends were also notified in terms of $\mathrm{P}$ and $\mathrm{K}$ contents of liquid organic fertilizer. Further research should be focused on using lower concentration of $\mathrm{Zn}$ for production of liquid organic fertilizer.

\section{ACKNOWLEDGMENT}

Sincere thank the University of Bengkulu for financing this research through 2019 Competitive Research Scheme (grant number 1963/UN30.15/LT/2019).

\section{REFERENCES}

[1]. T.K. Hartz, J.P. Mitchell, and C. Giannini, "Nitrogen and carbon mineralization dynamics of manures and composts", HortScience, vol. 35 , no. 2, pp. 209-212, 2000.

[2]. Z. Muktamar, S. Sudjatmiko, M. Chozin, N. Setyowati, and F. Fahrurrozi, "Sweet corn performance and its major nutrient uptake following application of vermicompost supplemented with liquid organic fertilizer", Int. J. Adv. Sci. Eng. Inf. Technol., vol. 7, no. 2, pp. 602-608, 2017.

[3]. F. Fahrurrozi, Y. Sariasih, Z. Muktamar, N. Setyowati, M. Chozin, and S. Sudjatmiko, "Identification of Nutrients Content in Six Potential Green Biomasses for Developing Liquid Organic Fertilizer in Closed Agricultural Production System", 'Int. J. Adv.
Sci. Eng. Inf. Technol., vol. 7, no. 2, pp. 559565, 2017a.

[4]. F. Fahrurrozi, Z. Muktamar, N. Setyowati, M. Chozin, and S. Sudjatmiko. "Nutrient Properties of Tithonia-enriched Liquid Organic Fertilizer as Affected by Different Types of Animal Feces and Its Effects on Fresh Weight of Loose-leaf Lettuce (Lactuva sativa L.)", Int. J. Adv. Sci. Eng. Inf. Technol., Int. J. Adv. Sci. Eng. Inf. Technol., vol. 10, no. 2, pp.730-735, 2020.

[5]. B. Purnomo, F. Fahrurrozi, Y. Sariasih, Z. Muktamar, and Z. Efendi, "Determination of Potential Bacteria from Five Different Types of Green Biomass Enriched Liquid Organic Fertilizer for Developing Biodecomposer" Int. J. Agric. Tech., vol. 13, no. 7.1, pp. 1175-1182, 2017.

[6]. Chen, H. Magen, and J. Riov. "Humic substances originating from rapidly decomposing organic matter: properties and effects on plant growth", In: 'Humic substances in the global environment and implications on human health', N. Senesi, and T.M. Miano (eds), Elsevier Publishers, Amsterdam, The Netherlands. pp:427-444, 1994.

[7]. P. Veeranagappa, H.C. Prakasha, M.K. Basavaraja, and H.M. Saqeebulla, "Effect of zinc enriched compost on yield and nutrient uptake of rice (Oryzae sativa L.)." Eur. J. Biol. Res., vol. 3, no. 1, pp. 23-29, 2010.

[8]. M. Duan, J. Yang, J. Gu, X. Qian, W. Sun, H. Gao, and $X$. Wang, "Effects of sulphamethazine and zinc on the functional diversity of microbial communities during composting", Environ. Technol., vol. 37, no. 11, pp. 1357-1368, 2015.

[9]. P. Zaccheo, L. Crippa, and P.L. Genevini, "Effect of zinc on nitrogen transformation during composting process and in soil", In: $\mathrm{O}$. Van Cleemput, G. Hofman, A. Vermoesen (eds), "Progress in Nitrogen Cycling Studies. Developments in Plant and Soil Sciences", Springer, Dordrecht, vol. 68, pp. 165-169, 1996.

[10]. L. Gopalakrishnan, K. Doriya, and D.S. Kumar, "Moringa oleifera: A review on nutritive importance and its medicinal application", Food Sci. Hum. Well, vol. 5, no. 2, pp. 49-56, 2016.

[11]. O.J. Nava, C.A. Soto-Robles, C.M. GomezGutierrez, A.R. Vilchis-Nestor, A. CastroBeltran, A. Olivas, and P.A. Luque, "Fruit peel extract mediated green synthesis of zinc oxide nanoparticles", J. Mol. Struc., vol. 1147, pp. 1-6, 2017.

[12]. Z. Muktamar, Fahrurrozi, Dwatmadji, N. Setyowati, S. Sudjatmiko, and M. Chozin, "Selected macronutrient uptake by sweet corn under different rates of liquid organic fertilizer in Closed Agriculture System" Int. J. Adv. Sci. 
Eng. Inf. Technol., vol. 6, no. 1, pp. 258-261, 2016.

[13]. S. Yoshida, D.A. Forno, J.H. Cook, and K.A. Gomez, "Laboratory manual for physiological studies of rice" IRRI, Los Banos, Philippines, 83p, 1976.

[14]. Y. Lee, "Various microorganisms' roles in composting: A review". APEC Youth Scientist Journal, vol. 8, pp. 11-15, 2016.

[15]. Fahrurrozi, Y. Sariasih and B Purnomo. "Identifikasi sumber hijauan dan mikroorganisme eEfektif penyusun pupuk organik cair untuk produksi jagung manis dalam sistem pertanian tertutup", Final Research Report submitted to Research and Community Services Institute, University of Bengkulu. 2017b.

[16]. C.W. Bong, F. Malfatti, F. Azam, Y. Obayashi and S. Suzuki, "The effect of zinc exposure on bacteria abundance proteolytic activity in seawater'. In. 'Interdiciplianry Studies on
Environemntal Chemistry - Biological Responses to Contaminants", N. Hamamuraa, S. Suzuki, S. Mendo, C.M. Barroso, H. Iwata and S. Tanabe (eds), Terrapub, pp. 57-63, 2010.

[17]. T. Gonzales, and J. Robert-Baodouy, "Bacterial aminopeptidases: Properties and functions", FEMS Microbiol. Rev, vol.18, pp. 319-344, 1996.

[18]. M.I. Rashid, L.H. Mujawar, T. Shahzad, T. Almeelbi, I.M.I. Ismail, and M. Oves, "Bacteria and fungi can contribute on nutrients bioavailability and aggregate formation in degraded soils", Microbiol. Res., vol. 183, pp.26-41, 2016.

[19]. H. Khatoon, P. Solanki, M. Narayan, L. Tewari, and J.P.N. Rai, "Role of microbes in organic carbon decomposition and maintenance of soil ecosystem", Int. J. Chem. Stud., vol. 4, no. 6, pp. 1648-1656, 2017. 